\title{
Anthony Henry, 'Lilius,' and the Nova-Scotia Calendar
}

\author{
Anne Dondertman
}

Although almanacs had been popular throughout Europe for at least two centuries prior to the advent of printing, the new technology made them available to an ever increasing segment of the population. Gutenberg issued a sheet almanac in German for $1448,{ }^{1}$ and the earliest English almanac was probably one printed by Wynkyn de Worde for $1498 .^{2}$ In the colonies, too, almanacs were among the early products of the pioneer presses. Although the Bay Psalm Book is generally referred to as the first book printed in America, contemporary sources indicate that Stephen Day had earlier issued an almanac, compiled by William Pierce, a ship's captain. ${ }^{3}$ In Quebec, Brown \& Gilmore began to publish a sheet almanac soon after setting up their press in $1764{ }^{4}$

This essay will focus on the publishing history of just one early Canadian almanac, the Nova-Scotia Calendar, printed at Halifax by Anthony Henry. This, the first pamphlet almanac produced in Canada, continued for over three decades, from 1769 to the end of the century. However, the emphasis here will be on the first phase of the series, the five years between 1770 and $\mathrm{I} 774$, when the compiler was identified on the title-page as 'A. Lilius.' There are no surviving copies for 1769 or 1775 . The edition for 1776 was compiled by 'Rider, ${ }^{\prime 5}$ and after 1776 the author was identified as 'Metonicus' until the series ended upon Henry's death in I80o. The circumstances surrounding the publication of the almanac will be examined in some detail, including the social and economic factors that led up to its introduction, the way in which the printer set about producing it for the first time, the type of material it contained, and possible sources for both form and content.

Anthony Henry, the successor to John Bushell who was Nova Scotia's first practising printer, had already been in business in Halifax for approximately a decade before he issued the first of this series in $1769 .{ }^{6}$ The Nova-

Anne Dondertman is a librarian at the Thomas Fisher Rare Book Library, University of Toronto. 
Scotia Calendar was advertised as 'just published and to be sold' in the premier number of Henry's second newspaper, ${ }^{7}$ but no copies of this first Canadian almanac have been located. The first surviving example is the one for the following year, $1770 .^{8}$

By this time, almanacs had long been a staple of the early presses in the American colonies. One has only to glance through Drake's monumental bibliography of American almanacs to get an indication of the sheer quantity of material that was published..$^{9}$ In an article on Massachusetts almanacs written in I9 12, Charles Nicholas demonstrated the widespread popularity of almanacs in colonial times by compiling some statistics from Evans's bibliography of American imprints. He notes that of a total of 967 titles listed in Evans for the period I639-1700, after deducting religious works and government publications, 80 of the 150 items remaining are almanacs. ${ }^{10}$ Indeed, some of these titles were best-sellers of their day. Nichols claims, for example, that 50,000 copies of Nathaniel Ames's almanac were sold each year. ${ }^{11}$

One implication of such popularity is that almanac publication was a very important source of revenue for colonial printers. In England, of course, the lucrative almanac market had long been tightly controlled. In I57 I, Queen Elizabeth granted the first of three patents to Richard Watkins and James Roberts to print almanacs and prognostications, which, even at that time, were recognized as being 'a pretty commodietie toward an honest man's lyuing. ${ }^{12}$ After Watkins's death, James I granted a new patent to the Company of Stationers in 1603, which was later extended also to the Universities. However, as time went on, the Stationers' Company found it increasingly difficult to maintain their hold on the market. At various times in the eighteenth century, special arrangements were made with both Oxford and Cambridge, whereby the Universities received substantial payments in return for their agreement to refrain from printing almanacs. ${ }^{13}$ At this time too, the Company's monopoly began to be repeatedly challenged by the new provincial presses, as well as by certain London printers who churned out unauthorized editions despite warnings and even prosecution by the Company. Nevertheless, at the time Henry began his almanac series, the Company sold nearly half a million almanacs annually, which together generated a gross profit amounting to approximately $£ 2000 .{ }^{14}$ However, it was inevitable that the monopoly would be successfully challenged, and in 1775 a London printer named Thomas Carnan won his case against the Stationers' Company, thereby stimulating even more competition in an already crowded field. Carnan's almanacs celebrate his victory in a rather smug imprint:

Printed for T. Carnan, in St. Paul's Church Yard, who dispossessed the Statio- 
ners Company of the exclusive privilege of printing almanacks, which they had monopolized I 70 years, to the discouragement of genius and the great prejudice of the booksellers throughout the Kingdom, in consequence of a patent obtained from King James I. which his most sacred Majesty had no right to grant. ${ }^{15}$

Colonial printers were not hampered by any such official monopoly, and the almanac business there had long been fiercely competitive, with piracies and rival publications of all kinds competing for sales. The very success of a series like that of Ames's Astronomical Diary, which ran from I726 to I775, inspired all sorts of shady business practices. In 1760 , for example, a spurious production purporting to be a second edition of Ames's almanac for that year was issued, bearing a brazen warning to the public against the true copy. ${ }^{16}$ In the preface to his 1772 almanac, Nathaniel Ames Jr., who took over from his father in 1765 , discussed the intense rivalry among printers, which necessitated a marketing strategy in which publication was delayed

'till such a time as Almanacks are in greatest demand, that the original purchaser of the copy may have the utmost advantage of a quick sale to save enough to pay for the copy in the few days start he has of the other printers. ${ }^{17}$

Indeed, the younger Ames soon gave up his on-going battle with the printers and stopped compiling almanacs. In his book on the Ames series, Samuel Briggs quotes an extract from the younger Ames's diary in which he voices his bitterness: 'Never let me write again to the Printers of Boston News papers for they are all Knaves, Liars, Villains to serve their Interest \& when they appear most Friendly have most of the Devil in their Hearts.' Briggs further emphasizes the point: 'Dr. Ames bore on hard to the pen which wrote this entry. ${ }^{18}$

In view of the probable success of such a publication, it is perhaps surprising that Henry did not undertake the printing of an almanac sooner than he did. The existence of a market is attested to by the fact that one of the Boston printshops for a number of years included the Nova Scotia civil list in its register / almanac, obviously feeling that potential sales in Nova Scotia warranted the extra expense involved. Furthermore, the Boston publication undoubtedly reached its destination, for the issue for $1768^{19}$ appears as the first of a series of Nova Scotia almanacs collected by a contemporary, Isaac Deschamps, a judge and member of the House of Assembly for Nova Scotia, which are now in the library at Dalhousie University.

Aside from the possible impetus afforded by the existence of the Boston publication, Henry had other compelling reasons for publishing an 
almanac at this time. In October 1765 , he had hired as his apprentice the young Isaiah Thomas, who promptly embroiled him in difficulties with the authorities over the Stamp Act. The unfortunate consequence for Henry was that he lost not only his apprentice, but also his newspaper and his government printing work. The authorities were in a position to dismiss Henry because a new printer, Robert Fletcher, had arrived from England. Indeed, Tremaine comments that 'the newcomer [was] apparently brought from England for the purpose. ${ }^{20}$

In any event, between the time of Henry's loss of the Halifax Gazette in the spring or summer of 1766 , and January 1769 when he began a new weekly paper independent of government patronage, ${ }^{21}$ Henry must have been casting about for sources of income. Tremaine records no Henry imprints during this period when he was in competition with Fletcher. It is possible that by the end of 1768 , Henry did not even have sufficient capital to produce the almanac on his own. The advertisement in the newspaper runs as follows: 'Just Published and Sold, by A. Henry, W. Reynold, B. Phippen, and G. Marling. ${ }^{22}$ Phippen was a binder, and presumably the other two men were also Halifax merchants. This is the only year in which any of these names is found in connection with the printing of the almanac. During this period we also find Henry advertising printed blanks such as indentures and powers of attorney, ${ }^{23}$ another indication that he was anxious for business.

It is interesting to speculate about how a printer would have set about the task of producing an almanac for the first time. Henry would undoubtedly have been familiar with the format, because he himself had worked in the American colonies for a brief period before joining John Bushell's shop in Halifax. Nevertheless, no matter how much practical experience Henry may have had to draw on, it would be essential to work from a printed model in setting up the type, as the calendar pages in particular involve an extremely complex job of composition. British almanacs were certainly available in Halifax at this time. Robert Fletcher had set up a bookshop as well as a printing establishment when he arrived from England; he several times advertised an English almanac in Henry's paper in $1769 .{ }^{24}$ It has already been noted that at least one almanac from Boston was intended for sale in Halifax, and it is likely that Henry would have had access to almanacs from Pennsylvania and at least some of the other colonies as well. Any one of these could have been used as a model.

The popular British almanacs of the eighteenth century, such as those initiated by Wing, Moore, and Partridge, were continued after the death of the original compilers by anonymous editors appointed by the Stationers' company. These almanacs conformed to an established pattern, containing certain standard elements which varied little from title to title or decade to 
decade. They were printed in red and black, and contained three gatherings of eight leaves, with two pages being devoted to each calendar month, and the remaining twelve leaves taken up with astronomical calculations and other miscellaneous textual material, including the prognostications for the coming year. The material given on the two facing calendar pages remains remarkably consistent throughout the century. The pages begin with the moon's phases for the month and generally also include some poetry, usually reprinted from another source. Sundays and remarkable days are given a separate column from the aspects and weather, and observations take up the third major column, with the rest of the space containing astronomical information such as the times of sun and moon rise and set, and the moon's place in the zodiac (see illustration I).

The colonial almanacs of the mid-eighteenth century can be divided into two main groups, based on the layout of the calendar pages. Almanacs in the first group very closely resemble their British counterparts. They employ the double-page calendar format, and give the remarkable days and aspects in separate columns, generally including a table of the planets' places and a substantial column on the recto for text. In the second group, a single-page format for the monthly calendars is employed, combining courts, aspects, weather, and remarkable days in one column, along with maxims. The chaotic, crowded appearance resulting from the mixture of roman and italic type, along with astronomical symbols, is very typical of the American rather than the British style, and is similar also to the calendar pages found in Henry's Nova Scotia series (see illustrations 2 and 3 ).

In trying to determine possible sources for the Nova-Scotia Calendar, American almanacs produced in the mid-I 760 s, just before Henry began his own series, were examined making use of the Evans microfiche. ${ }^{25}$ In I768, for example, almanacs were produced in fourteen different locations: at Annapolis, Boston, Charlestown, Germantown, Hartford, New Haven, New London, Newport, New York, Philadelphia, Portsmouth, Providence, Williamsburg, and Wilmington. Some of these are local editions of established titles. Ames's Astronomical Diary, for instance, appeared in two editions in Boston, and was also issued by printers in Hartford, New Haven, Newport, and Portsmouth.

Of the colonial almanacs examined, the Boston publications, which all employ the single-page calendar format, demonstrate the most similarities to Henry's series. In addition to Mein and Fleeming's register / almanac, ${ }^{26}$ which has already been mentioned as being available in Nova Scotia, there were three other Boston almanacs for 1768 , the year before Henry began publication; they were compiled by Nathaniel Ames Jr., ${ }^{27}$ Nathaniel Low, ${ }^{28}$ and Benjamin West. ${ }^{29}$ The Ames and Low almanacs are very similar. Nathaniel Low, who began his series in 1762 , blatantly modelled his 
almanac on that of Ames, even using a virtually identical title, and they were clearly in direct competition with each other. The year 1768 marked the first appearance of a new competitor, Benjamin West, who revived the pseudonym used by Jonathan Swift in his attack on Partridge in 1707 , in an almanac entitled Bickerstaff's Boston Almanack. Based on a comparison of the layout of the calendar pages of the four Boston almanacs for 1768 , Henry's most closely resembles that of Ames.

Although the Ames almanacs are therefore a possible source for the physical format of Henry's series, we are left with the problem of sources for the actual text, both the astronomical calculations themselves and the miscellaneous material making up the rest of the almanac. Leaving aside for the moment the astronomical data appearing in the preliminaries and on the calendar pages, and turning to the written matter, one notes that the material appearing in Anthony Henry's almanacs between 1770 and 1774 is extremely diverse.

The issues for 1770 and $177 \mathrm{I}$ are obviously heavily influenced by British models as well as by colonial American almanacs. The section on weather in 1770 gives rules for forecasting based on observations related to sunrise and sunset, which had been present in British almanacs for two centuries. The number for $177 \mathrm{I}$ ends with the standard predictions for the four quarters of the year based on such factors as what day of the week New Year's day falls on. This type of material was still very common in eighteenthcentury British almanacs, although it is not found in American almanacs of the period. The number for 1770 also contains the narrative of a comic escapade of a youth in Paris, as well as a very sober piece on the theme of the vanity of earthly ambition. The next year includes an extract from a history of commerce and a couple of bawdy poems. Instead of the usual preface, in the 1772 almanac there is a letter in response to a reader's question, which ends: 'and if you should still be curious in this matter, so far as to desire a Rule for performing the Opperation [sic] in future, you must go to school and study for it as I have done.' In 1773 there are a number of short essays on religious themes, a section of veterinary hints, and a 'History of a new island which rose out of the sea, near Isle Santorin, in the Archipelago, in 1707. ' In 1774 there is an entertaining piece entitled 'A moral and political map of Europe. ${ }^{30}$

By the end of the first half dozen years of this first almanac series in Canada, in addition to the essays and literary matter just mentioned, one can also see evidence of much of the material that is to be found in later almanacs: the civil list / register; domestic and health hints; agricultural and veterinary advice; humour and entertainment; advertisements; roads and distances; and militia lists. The one thing that is not evident in the Nova-Scotia Calendar at this early period is the tradition, found in both 
Britain and the American colonies, of individual compilers putting the stamp of their character on their publications and using them as a vehicle for expressing their own political views. Although many of the compilers of the colonial American almanacs are well known despite their pseudonyms, compilers of the earliest Canadian almanacs have not been identified, and the question of the identity of 'Lilius' remains to be investigated.

The almanac itself does not offer many clues as to authorship. In the preface to the edition for 1773 , signed 'A. Lilius,' the author thanks the public 'for their kind acceptance of my annual Labours for these four Years past ..., ${ }^{\prime 31}$ implying that the same person has been responsible for the series from 1770 to 1773 . The pseudonym, which was used for the last time the following year (1774), recalls William Lilly, the most celebrated English astrologer of the seventeenth century, whose extremely popular series, Merlini Anglici Ephemeris, ran from I644 to I682. The use of pseudonyms was, of course, commonplace at this time. Local contributors to Henry's newspaper also employed either initials or pseudonyms, and one reason for the prevalence of this practice was undoubtedly to disguise the fact that the production was actually the work of the printer.

It is likely that the more successful the compiler, the more he contributed to the content of the almanac; however, printers evidently were free to fill up any available blank space with whatever material they had on hand. In Low's almanac for 1767 we find an unusually candid admission of this on the page after the preface: 'The following is inserted by the Printer to fill up a vacant page. ${ }^{.32}$ In a New York almanac for the same year, the compiler comments on the weather predictions found on the calendar pages:

The influence of the Planets is altogether imaginary, and the Almanack Makers are as utterly ignorant of all future Events as you are; ask them, and they cannot deny it. Indeed few of them pretend to know any Thing about it, but put in, or leave it to the Printers to put in something of the Weather, wherever there happens to be room for it ... ${ }^{33}$

Although it was common for printers to supply at least some of the text in early almanacs, it is doubtful whether Henry himself would have been capable of making such a contribution. Isaiah Thomas describes him as 'a very unskilful printer,' and then goes on to say that 'to his want of knowledge or abilities in his profession, he added indolence; and, as is too often the case, left his business to be transacted by boys or journeymen, instead of attending to it himself. ${ }^{34}$ McCulloch, in his 'Additions to Thomas's History of Printing,' reports that Henry Stirner, who had worked for Anthony Henry in Halifax in the 1780 s, described Henry not just as unedu- 
cated but as practically illiterate: 'Henry was a poor botch of a printer, and as poor a scholar. He could scarcely write his own name. Stirner conducted his paper while he resided with him: before and after that period it was conducted by Henry's men or boys. ${ }^{35}$ Regardless of how much truth there may be in these assessments of Henry's intellectual and typographical abilities, and even if Henry had an able assistant or managed to plagiarize much of the textual material from other sources, he would still have had to obtain the astronomical data pertaining to Halifax from someone with special training. Richard A. Jarrell, in his book on the history of Canadian astronomy, although he does not specifically discuss almanacs, states that very few colonists prior to 1840 had the skills and training which would have been needed to perform the complex calculations required: 'The colonists themselves rarely initiated or performed any astronomical work. Only a handful of colonists ever learned the rudiments of hydrography, surveying, or astronomy. ${ }^{136}$ This, perhaps, is one explanation of why Henry did not produce an almanac sooner. We are left with two possibilities. Henry may have turned to, or been approached by, a local citizen with special skills, such as a surveyor, ${ }^{37}$ or he may have communicated with a compiler from elsewhere.

A close examination and comparison of astronomical calculations by compilers of the eighteenth century reveals the somewhat surprising fact that they are quite distinctive to each individual, and can be used as a basis for attribution. ${ }^{38}$ If, for example, one compares a Boston almanac for 1773 compiled by Samuel Stearns ${ }^{39}$ with one compiled by Ames for the same year ${ }^{40}$ it is evident that there are innumerable small differences in the calculations given in the four columns of astronomical information on the calendar pages (sunrise, full sea, moon's place, and moonrise) ${ }^{41}$ An examination of the type of calculations found in the Nova-Scotia Calendar indicates that the compiler of Henry's almanac is probably not the same person who had been supplying the calculations for the Quebec sheet almanac, which was the only other almanac being produced in Canada at the time. The strong trade links that existed between Nova Scotia and the American eastern seaboard make it much more likely that Henry was in touch with a compiler from Boston or Philadelphia. If Henry did use an American compiler, then it would be reasonable to focus first on those whose almanacs were published in Boston, since their similarity to Henry's series has already been noted. And, in fact, while examining the various colonial almanacs printed during the early I770s, I came across evidence linking Samuel Stearns of Boston with Henry's production.

According to his biographer, Stearns was born in Bolton, Massachusetts in $\mathrm{I} 74 \mathrm{I}$ and practised medicine as well as compiling almanacs. As a loyalist, he was subjected to considerable harassment during the revolutionary 
period, which culminated in his arrest in 1780 , at which time he managed to escape to the British in New York. At the end of the war he returned home, intending to emigrate to Nova Scotia, but in 1784 he was again arrested and spent the next three years in jail in Worcester. After his release in 1787 , he travelled to Montreal to seek compensation from the British, but arrived too late to have his case heard. At this time he also visited Quebec City. He was still involved in almanac calculations as late as I 807 , and died in I $809 .{ }^{42}$

The evidence connecting Stearns with the Nova-Scotia Calendar can be summarized as follows: (I) The beginning and ending dates of Henry's series coincide with the dates when Stearns was compiling almanacs in Massachusetts before the revolution. (2) Stearns was involved in calculating for other parts of British North America, including New Brunswick and Quebec. (3) There are significant textual similarities. Let us examine each of these points in more detail.

Nathaniel Ames Jr. recorded in his diary for February I 768: 'Sam. Sterns [sic] of Boston wants to know how to make almanacs. ${ }^{43}$ Although both Clark and Nichols record I770 as the date of Stearns's first almanac, it is almost certain that he was responsible for the series entitled The NorthAmerican Almanack published by Edes \& Gill in Boston starting in 1769 . Stearns was named on the title-page from I77 I until I775. The edition for $1769^{44}$ appears to be the work of an amateur or novice, for only the most rudimentary astronomical information is included in the calendar pages (sunrise / set, moonrise / set, and full sea). The preface of the I 770 almanac, attributed to Stearns by Evans, refers to 'the kind reception which my last year's Almanack has met with, ${ }^{45}$ clearly suggesting that the same person was responsible for both years. It would be interesting to compare the 1769 calculations with those for Henry's almanac for that year, but unfortunately, as has been noted above, there are no surviving copies of Henry's first almanac.

It was stated previously that Henry's almanac for 1776 was evidently by a new compiler, identified as 'Rider' on the title page. This was just about the time that Stearns, a loyalist, was running into problems because of his politics. In a pamphlet printed by Isaiah Thomas in 1786 , Stearns states that some of his astronomical productions at the outbreak of the revolution were destroyed, and that their circulation through the States was totally impeded. ${ }^{46}$ The claim he made to the British government for loss of income due to harassment was dated from the year 1775 . Stearns apparently did calculate, and had published, an almanac for $1776 .{ }^{47}$ It could well be, however, that due to the general disruption in the colonies at this time, Stearns's calculations for 1776 did not reach their out-of-town destinations. One of the charges against Stearns was that of corresponding with 
the enemy, which at that time meant anyone living under British rule. It would be helpful to know whether Henry's 1776 almanac was published later than usual, but the advertisements are not available because the newspapers from November 1775 until the following May have not survived. However, Henry's almanac for 1776 , attributed to 'Rider' on the title-page, certainly does show signs of having been hurriedly compiled. The moon's place column is lacking, as is some of the other astronomical information. Furthermore, the data given on the calendar pages is evidently totally inaccurate, for the copy at Dalhousie has extensive manuscript corrections in both the inner and outer margins for each day of the month. Furthermore, Henry has lifted a whole section of text ('The life and adventures of a female soldier') verbatim from a Massachusetts almanac of the previous year - Thomas's New-England Almanack. ${ }^{48}$ The year following the 'Rider' fiasco, Henry evidently looked elsewhere for his copy, for it marks the first of his almanacs for over twenty years to be compiled by 'Metonicus.' In her description of the first of the Metonicus series in 1777 , Tremaine comments that the tone of the series changes at this point: 'The Metonicus calendars are, on the whole, more sedate and scientific than their predecessors. ${ }^{49}$

It is known that Stearns did contribute to almanacs for other parts of the British colonies. In the preface to his almanac for 1787 , Stearns remarks that for some years past he had calculated almanacs for four different governments on the continent. ${ }^{50}$ In I79I, on the title-page of his book The American Oracle published in London, he calls himself 'Astronomer to his Majesty's Provinces of Quebec, and New Brunswic [sic]; also to the Commonwealth of Massachussetts, and the State of Vermont. ${ }^{51}$ In I 802, he adds Montreal to the list of places where his productions were published. ${ }^{52}$ Although he never specifically names Nova Scotia, the fourth government mentioned in the 1787 almanac remains doubtful, for, as Clark points out, his first Vermont almanac was for 1788 and the Quebec publications probably date from the time of his travels there in $1787^{.53}$ Clark has identified only one item published in Canada, An Astronomical Diary for $1786,{ }^{54}$ printed in Saint John by Christopher Sower and compiled by 'Julius Scaliger. ${ }^{55}$ Stearns was still in jail in Worcester when he prepared the calculations for the New Brunswick almanac, as well as for Isaiah Thomas's almanac for the same year. ${ }^{56}$

The basis for Clark's attribution, aside from Stearns's own statements regarding his calculations for New Brunswick at this period, is largely textual. ${ }^{57}$ The chronology in this New Brunswick almanac is very similar to one published under Stearns's own name for 1788 at Boston. ${ }^{58}$ Clark comments that Stearns was particularly fond of compiling these historical chronologies. ${ }^{59}$ He believes that Stearns also calculated at least one 
almanac each for Quebec and Montreal, probably for 1787 or $1788 .^{60}$ Searching through Tremaine for the I780s and I790s, for Quebec and Montreal imprints, one is seriously hampered by the number of items 'not located.' However, the Almanach de Québec for $1787,{ }^{61}$ published by Brown as part of a series which began in 1780 , does include a chronology virtually identical to that found in the New Brunswick almanac of the previous year which has been attributed to Stearns. The Almanach de Québec had been printed mainly in French from its beginning, although some text, such as official proclamations, appeared in English and French, usually side by side. In the 1787 edition, we find the chronology, a $6 \%$ interest table (which is another Stearns trademark), and a page of rules for converting foreign currency in English only. The eclipses are also given in English as well as French this year for the first time. If Stearns was directly responsible for the English language material in this almanac, then $I 787$ is probably the only year he contributed to the Almanach de Québec. The 1788 and 1789 editions do not contain any English text which could be attributed to him.

It may seem curious that Brown would have commissioned Stearns for just one year in the middle of a successful ongoing series. However, this series shows significant diversity from year to year, even in the type of astronomical information given on the calendar pages. It is possible that Brown had no one reliable compiler, and had to turn to different individuals each year. This appears to have been the case with the Brown \& Gilmore sheet almanac as well. Samuel Holland, for example, provided calculations for just one year $(\mathrm{I} 772),{ }^{62}$ although the series had been ongoing since 1765 .

There is one other possibility for a Stearns item in Québec. William Moore is known to have published an almanac for 1789 , which contained both a chronology and a $6 \%$ interest table, ${ }^{63}$ but once again, unfortunately, there are no surviving copies. The Montreal item remains uncertain. There are no obvious candidates among the surviving publications by Mesplet between I776, when he began printing an almanac in Montreal, and I786, when the series ended. After Mesplet's death in I794 a number of sheet almanacs was produced in Montreal, but none of these appears to be by Stearns.

The evidence presented thus far for the identification of Stearns with 'Lilius' is, admittedly, largely circumstantial, but there are also significant textual similarities linking Stearns with the Nova Scotia series. In Henry's almanacs for 1773 and I774, instead of the customary verse at the top of each calendar page, is a chronology of events which is identical to one printed in the Boston almanac compiled by Stearns for the same two years. 

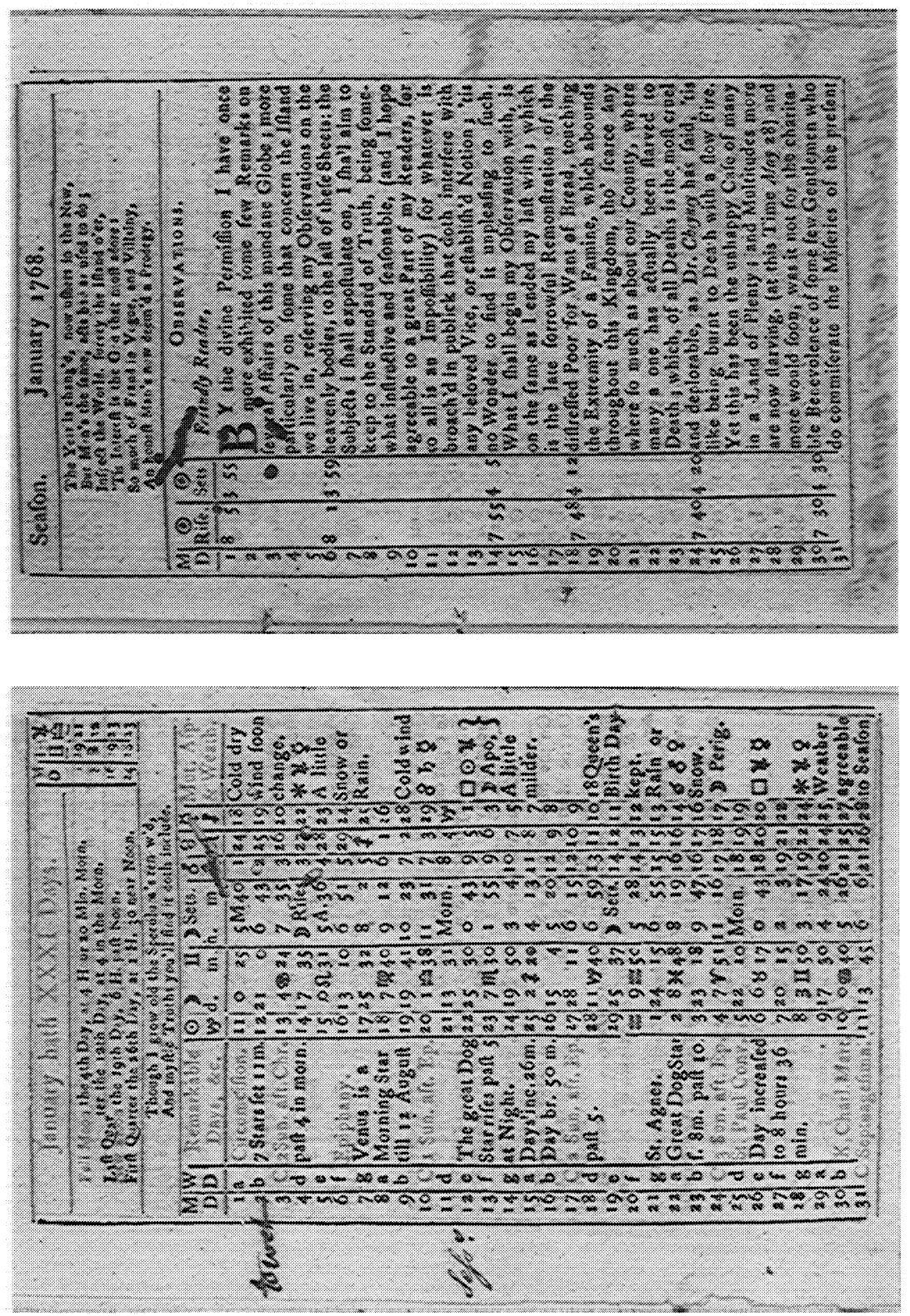

Henry Season, Speculum Anni, or, Season on the Seasons Being an

Almanack ... 1768. London: Printed by T. Parker for the Company of

Stationers. (Photograph courtesy of the Thomas Fisher Rare Book Library, University of Toronto.) 

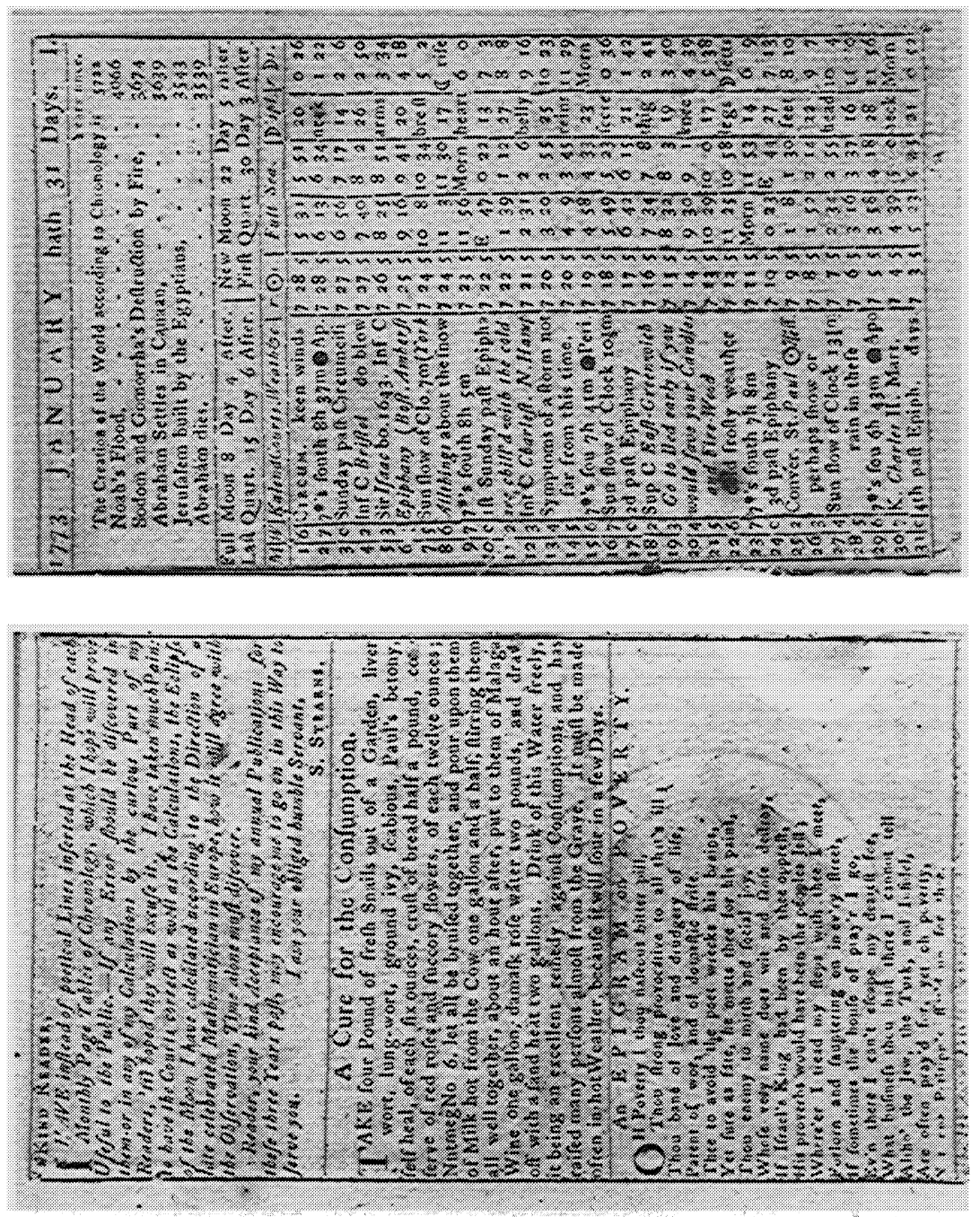

Samuel Stearns, The North-American's Calendar and Gentlemen and Ladies Diary, Being an Almanack For ... 1773. Boston: Printed and sold by Edes \& Gill and T. \& J. Fleet. (Photograph courtesy of the American Antiquarian Society.) Evans I 2566. 

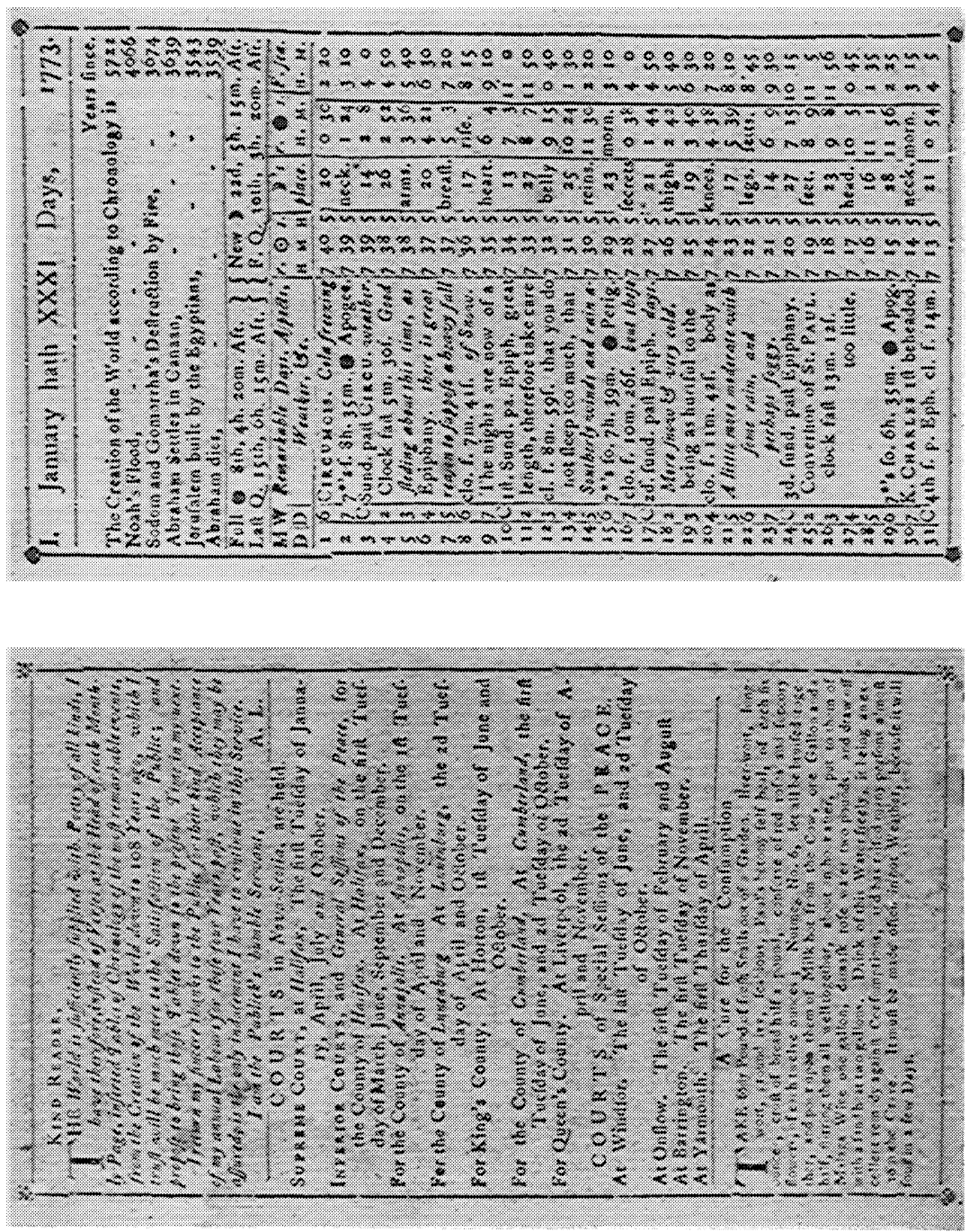

A. Lilius, The Nova-Scotia Calendar or an Almanack For ... 1773. Halifax: Printed and sold by Anthony Henry at Mr. Robert Fletcher's store, and at Mr. Francis Bonds. (Photograph courtesy of the J.J. Stewart Collection, Special Collections Department, Dalhousie University Library.) Tremaine I63. 
The prefaces in the Boston and Halifax almanacs for 1773 are also very similar, and a short piece entitled 'A cure for the consumption' is identical in both (see illustrations 2 and 3). However, the rest of the material in the almanacs for these two years is completely different.

One might suppose that a comparison of the actual astronomical calculations in the Boston and Halifax almanacs might offer further clues to authorship, since it has already been pointed out that these calculations can vary a good deal from compiler to compiler. Although it is more difficult to make comparisons when the almanacs are calculated for different places, some of the information, such as the moon's place column, is unaffected by geographic location. A comparison of the January moon's place column in Stearns's 1773 Boston almanac with Henry's for that year indicates that they differ in only one instance (see illustrations 2 and $31 .{ }^{64}$ The Ames almanac for $1773,{ }^{65}$ in contrast, differs from Stearns's almanac for that year in six instances in the moon's place column for January.

It must be said, however, that this sort of comparison is far from satisfactory, because some of the differences could well be the result of errors in the printshop. Eighteenth-century almanacs, particularly the calendar pages, are notoriously ill-printed. They were generally put together as quickly and cheaply as possible and may not have been proofed at all. Printers and compilers are often recorded wrangling over typographical errors. In 1774 , for example, Stearns elicited an apology from the printer for an error in the calendar pages of Freebetter's Connecticut Almanac ${ }^{66}$ which he compiled. ${ }^{67}$

Turning again to a consideration of the main body of text, apart from the astronomical calculations, one must keep in mind, in attempting to determine authorship, that even almanacs for the same year and by the same compiler can differ very significantly in their contents. For example, there are two almanacs with the same title by Stearns for 1788 , issued by different printers, in different places. ${ }^{68}$ Neither the chronologies nor the prefaces in these two almanacs are identical, although they are very similar, and the rest of the material is completely different. Likewise, the material that is common to the two American Stearns almanacs for $1773,{ }^{69}$ even if we consider only the calendar pages, is minimal. But just as differences in text do not necessarily imply different compilers, so similarities of text, even when they occur in the preface, do not constitute conclusive proof of authorship. It is quite possible that the printer has simply plagiarized material from a rival publication, as Henry did in his 1776 almanac, as noted above. However, the argument for the direct involvement of Stearns with the Nova-Scotia Calendar is strengthened somewhat by the fact that, in this case, the duplicated material appears in almanacs for the same year rather than successive years. Even so, Henry could have reprinted the 
material from the Boston almanac, which may have been issued before his own for that year. The only fact that remains certain is that material written by Stearns does appear in the Nova-Scotia Calendar, in at least two of the five years during which it was compiled by 'Lilius.'

The business of attribution is extremely difficult, because of the common practice of plagiarization, because authors used multiple pseudonyms while working for more than one printer at a time, and above all because it is almost impossible to distinguish the various contributions of printer and author. The entire question of the contribution made by the printer to the form and content of the almanac has not received much attention, except in the unusual cases when compiler and printer are one, such as the famous Franklin series. Yet it is surely a very significant one, in view of the fact that commentators from Bosanquet on have compared the influence of the almanac to that of the Bible, in terms of the mass market which it was able to reach. ${ }^{70}$

An examination of the publishing history of the Nova-Scotia Calendar between 1770 and 1774 suggests that almanacs are the products of a particular printshop, rather than any individual author, and thereby highlights once again the very important role that printers played in the community. Demonstrating a blend of British and American influences, but without either the rigid traditionalism of the British or the brashness of the Americans, 'Lilius' somehow managed to steer a middle course. The first series of almanacs produced by Henry's printshop is fascinating precisely because it still has some of the rough edges. It has not yet become a homogeneous production, but consists rather of a decidedly haphazard mixture of material from diverse sources. Although lacking a distinctive or at least readily definable character of its own, it is nevertheless true that as time goes on, the Nova Scotia almanac has more in common with an early New Brunswick or Upper Canada almanac than it does with either a Boston or London imprint. Modest and useful little pamphlets, they offered information and a sober kind of entertainment: practical advice to farmers; domestic hints; admonitions to be thrifty and hardworking and honest - messages which were read and re-read by an astonishingly large segment of the population and which helped to form and build a pioneer society. The printer's role, in both defining and reflecting that culture, was not inconsiderable.

NOTES

I Bernard Capp, Astrology and the Popular Press: English Almanacs 1500-1800 (London and Boston: Faber \& Faber, 1979), p. 25; Gesamtkatalog der Wiegendrucke (Leipzig: Verlag von Karl W. Hiersemann, I925-40), 2385.

Eustace F. Bosanquet, English Printed Almanacks and Prognostications: 
A Bibliographical History to the Year 1600 (London: Printed for the Bibliographical Society at the Chiswick Press, I917), v; Alfred William Pollard, A Short-Title Catalogue of Books Printed in England, Scotland and Ireland and of English Books Printed Abroad, 1475-1640, 2nd ed. (London: Bibliographical Society, I976-86), 385.3.

3 Marion Barber Stowell, Early American Almanacs: The Colonial Weekday Bible (New York: Burt Franklin, I977), pp.37-8; Charles Evans, American Bibliography (Chicago: priv. print, 1903-34), 2.

4 The first of this series was announced for publication on 2I Jan. I765. See Marie Tremaine, A Bibliography of Canadian Imprints, 1751-1800 (Toronto: University of Toronto Press, I952), 57.

5 Tremaine 195. The copy Tremaine examined was defective, but Dalhousie University Library later acquired a second copy with a title-page.

6 Tremaine II9.

7 The Nova-Scotia Chronicle and Weekly Advertiser, issue for 3 Jan. I769.

8 Tremaine I27.

9 Milton Drake, Almanacs of the United States (New York: Scarecrow Press, 1962).

Io Charles L. Nichols, 'Notes on the Almanacs of Massachusetts,' Proceedings of the American Antiquarian Society, N.S. 22 (I9I2), p. I8.

I I Ibid., p. 27.

I 2 Bosanquet, English Printed Almanacks, p. 9.

I3 Capp, Astrology and the Popular Press, p. 240.

I4 Cyprian Blagden, 'Thomas Carnan and the Almanack Monopoly,' Studies in Bibliography, I4 (196I), pp. 2 I-2.

I5 Reuben Burrow, The Ladies and Gentlemens Diary, or, Royal Almanac for ... 1777 (London: Printed for T. Carnan, [1776], title-page.

I6 Evans 8295 .

17 Evans I1962.

I 8 Samuel Briggs, Essays, Humor, and Poems of Nathaniel Ames, Father and Son, of Dedham, Massachusetts, from their Almanacks 1726-1775 (Cleveland: Short \& Forman, I891), p. 33 .

I9 Evans 10687.

20 Tremaine, p. 6or.

2 I The Nova-Scotia Chronicle and Weekly Advertiser (see Tremaine, pp. 602-4).

22 Ibid., issue for 3 Jan. 1769.

23 Ibid., issue for 24 Jan. 1769.

24 For example in the issue for 20 June 1769 he advertises The Court and City Kalendar.

25 Early American Imprints [microfiche], ed. Clifford K. Shipton (Worcester, Mass.: American Antiquarian Society, 1956-64).

26 Evans 10687.

27 Evans I0540. 
$$
\text { Printing,' ed. Clarence Saunders Brigham, Proceedings of the American }
$$
Antiquarian Society, N.S. 3 I (I92I), p. I78. This is as reported to McCulloch by Stirner, who was working as a printer in Philadelphia at the time McCulloch was compiling his notes (I 8 I 4-I5).

36 Richard A. Jarrell, The Cold Light of Dawn: A History of Canadian Astronomy (Toronto: University of Toronto Press, I988), p. 25.

37 The Surveyor-General, Samuel Holland, for example, provided the calculations for the Quebec sheet almanac for 1772 . See Tremaine 157.

38 This point has recently been emphasized in a very interesting article by the cataloguer of the almanac collection at the American Antiquarian Society. See Richard Anders, 'A Cataloguer and his Almanacs,' The Book: Newsletter of the Program in the History of the Book in American Culture, No. 20 (March I990), p. 5.

39 Evans I 2566.

40 Evans 12303.

4I Comparing the calculations given for the first day of January 1773 (under the same headings): Stearns: 728 5/531/20/026; Ames: $7325 / 530 / 20 / 028$

42 John C.L. Clark, 'The Famous Dr. Stearns,' Proceedings of the American Antiquarian Society, N.S. 45 (I935), pp. 317-88.

43 Briggs, Essays, Humor, and Poems of Nathaniel Ames, p. 34.

44 Evans i I078.

45 Evans II479.

46 Samuel Stearns, A Short History of the Treatment that Dr. Samuel Stearns Hath Met With in Massachusetts (Worcester: Isaiah Thomas, I786), p. 4 (Evans 20006).

47 Evans I4473.

48 Evans 13299.

49 Tremaine 224.

50 Evans 20007. These were for Massachusetts, Connecticut (he was the author of the Freebetter's almanacs for 1772-I774, see n.67 below), New Brunswick, and one other.

5 I Samuel Stearns, The American Oracle (London: J. Lackington, I79I).

52 Clark, p. 389n. 
53 Ibid., p. 389 .

54 Tremaine 446.

55 Presumably a conflation of the names of Julius Caesar Scaliger, I 484-I 558, a philosopher and scientist, and his son Joseph Justus Scaliger, I 540-1609, author of De Emendatione Temporum (Paris, I 583), who revolutionized the system of ancient chronology.

56 Evans I9027.

57 Clark, pp. 40I-2.

58 Evans 20725.

59 Clark, p. 392.

60 Ibid., p. 389.

6I Tremaine 473.

62 Tremaine 157.

63 Tremaine 548.

64 I.e., for Jan. 26, where Stearns has 22 and Henry has 23.

65 Evans 12303.

66 Evans 12744.

67 The Freebetter's almanacs for I 772-74 are usually attributed to Nathan Daboll, but Clark argues very convincingly that they were actually compiled by Stearns. See Clark, 'The Famous Dr. Stearns,' pp. 393-5.

68 For Boston, Evans 20725; for Vermont, Evans 20726.

69 For Boston, Evans I 2566; for Connecticut, Evans I 237 I. See n.67 above.

70 Bosanquet, p. vii. 